\title{
Concept-driven Design for Democracy: Advancing Co-creative Media to Support Citizen Participation and Democratic Engagement
}

\section{Montathar Faraon}

Department of Design, Kristianstad University, S-291 88, Kristianstad, Sweden

E-mail: montathar.faraon@hkr.se

Abstract: This article expounds on a concept of co-creative media that aims to support the democratic engagement of citizens by facilitating participatory and co-creative processes. The research is based on a concept-driven design approach to theoretically underpin and empirically inform the concept. This was accomplished by adopting theoretical resources from the framework of actor-network theory (ANT), identifying criteria from an analysis of existing sociotechnical systems for democratic engagement, and building on the results of four research studies. The main contribution of the article, namely the concept of co-creative media, could serve as a basis for further theoretical reflections and a point of departure for supporting future participatory design processes in which relevant stakeholders collectively contribute to the implementation and evaluation of co-creative media. Co-creative media have the potential to broaden citizens' democratic engagement through creating virtual spaces in which new ideas, initiatives, knowledge, and solutions could emerge.

Keywords: co-creative media, democracy, actor-network theory, concept-driven design, sociotechnical systems

Acknowledgement: The author thanks Victor Villavicencio for his help with the illustrations.

\section{Introduction}

Democracy has gone through a transition period of growth since the mid-1970s, with 30 percent of nations fulfilled the criteria of electoral democracy. By 2007, about 60 percent of nations were considered democratic (Diamond, 2015). Despite this surge in democracy, evidence has confirmed a disconnect between citizens and their representatives (Dalton, 2004; Hibbing \& Theiss-Morse, 2001). One reason behind this could be a potential change in direction from representation towards participatory modes of democracy in decision-making (Baiocchi, 2005; Rios Insua, Kersten, Rios \& Grima, 2008) and the co-creation of policy (Cremer \& Mullenger, 2016; Fillmore-Patrick, 2013). The emergence of information and communication technologies (ICTs) have been praised by repre- 
sentatives as a possibility to bridge the mentioned disconnect between themselves and their constituents (Hoff, 2004; Ward \& Lusoli, 2005). Digital technology has strengthened the voice of citizens within democratic processes, enabled the creation of virtual spaces and opportunities for activism, and promoted government accountability (Zanello \& Maassen, 2011). Building on digital technology, several social media platforms, such as Facebook and Twitter, have emerged where citizens can connect, communicate, and collaborate with each other. While these services were not developed with democracy in mind, they have been utilized for this purpose: to mobilize crowds for protests, rally citizens behind political agendas, and promote democratic transitions. Such protests and transitions have been witnessed at a macro level of society, for example, the London riots in the UK, the Indignados in Spain, Tahrir Square in Egypt, Occupy Wall Street in New York, and the subsequent global Occupy Together movements (Castells, Caraca, \& Cardoso, 2012; Mason, 2012).

Despite the ubiquity of social media platforms, their democratic usefulness can still be described as marginalized and other uses predominate such as social interaction and entertainment (Loader \& Mercea, 2012, p. 222). The technical prerequisites exist to go beyond the abovementioned uses and towards forms of activities encouraging proactive, participatory, and co-creative democratic processes (Erikson \& Vogt, 2013; Faraon, Villavicencio, Ramberg, \& Kaipainen, 2013; Olphert \& Damodaran, 2005; Paulin, 2014). Based on the considerations described above, the goal of this article is to offer both a theoretical and an empirical background to conceptually advance media with the aim of facilitating democratic, participatory, and co-creative processes for citizens. In the context of this article, and partially based on existing socio-technologies, the media suggested here are referred to as co-creative media.

Co-creative media can be defined as socio-technical systems (STSs) that integrate and adapt existing information and communication technologies (ICTs) with the aim of facilitating democratic engagement in terms of proactive, collective contributions, and consensus-seeking towards common interests. The concept of co-creative media has previously been proposed (Faraon et al., 2013) and will be furthered in this article in the form of an elaborated concept based on four previous studies. The first study is related to the concept of co-creative media (Faraon et al., 2013), which served as a starting point for the development of co-creative media that could be used by stakeholders for discussing, designing, and reflecting on participatory tools. The second study focused on the use of Internet voting for democratic engagement (Faraon, Stenberg, Budurushi, \& Kaipainen, 2015), which revealed that the majority of participants were positive in their attitudes towards using Internet voting for participation in democratic processes. At the same time, they were skeptical about the possibility of solving related security issues. The third study, which concerned the influence of online information on attitudes and voting behavior (Faraon, Stenberg, \& Kaipainen, 2014), investigated how online content conveyed by online news platforms versus social networking sites influenced participants' explicit and implicit attitudes and voting behavior. The results indicated that valenced information emanating from online news channels had a significant influence on both explicit and implicit attitudes, while social networking sites did not. The fourth article reviewed research on circumvention media and examined how different technologies could be repurposed to develop novel crossmedia services to support the free flow of information under conditions of censorship (Faraon, Atashi, Kaipainen, \& Gustafsson, 2011). 
With the prior work in mind, the research process of this article is guided by the following question: How can the concept of co-creative media be furthered both theoretically and empirically to facilitate the democratic engagement of citizens? The question will be addressed by applying the methodological approach of Stolterman and Wiberg (2010), namely concept-driven design research. The outcome of this article is the theoretically and empirically grounded concept of co-creative media, which will be elaborated in the fourth section and may be used to guide future design of democratic engagement.

The article is structured as follows. Section 2 conducts a theoretical review of the challenges and opportunities of democracy, as well as how the framework of actor-network theory (ANT) could theoretically underpin the concept of co-creative media. The next step is an analysis of existing socio-technical systems for democratic engagement, which gives rise to a set of criteria that should ideally be fulfilled by the concept of co-creative media. Section 3 describes the research methodology, namely the concept-driven design approach, and the way in which it was adapted to the current research process. This process generated four peer-reviewed articles, henceforth referred to as studies 1-4, the results of which were used to theoretically and empirically advance the concept of co-creative media. Section 4 further expands on the concept of co-creative media based on the theoretical underpinnings of ANT, the results of the four mentioned studies, and the criteria identified in the analysis of socio-technical systems for democratic engagement. Section 5 concludes the article by presenting remarks concerning the potentials of co-creative media and providing suggestions for future work.

\section{Background}

\subsection{Challenges and Opportunities for Democracy}

In the mid-1970s, democracy underwent a transition and has now become the foundation of many nations. At that point in history, a major surge occurred in democratic transitions, with 30 percent of nations fulfilling the criteria for electoral democracy, thus allowing citizens to choose and replace their leaders through free and fair elections (Diamond, 2015). Between the years 1975 and 2007, the number of these nations fluctuated between 114 and 119, corresponding to 60 percent of all nations (Diamond, 2015). The expansion of democracy can be interpreted as "the perceived universality of democratic principles and their assumed compatibility with diverse religious and cultural traditions" (Mulder, 2014, p. 436). While citizens may have accepted the notion of democracy, evidence has repeatedly indicated an increasing disconnect between citizens and their elected representatives (Dalton, 2004; Hibbing \& Theiss-Morse, 2001). This widening gulf has often been attributed to several interdependent factors, namely (Rachel, Wainer, \& Stephen, 2008, p. 113):

- Declining citizen knowledge and interest in representative politics.

- Declining levels of trust in politicians and representative institutions.

- Declining levels of efficacy amongst citizens, i.e., a declining belief by the public that they can influence government. 
- Declining levels of public identification and engagement with representative institutions, notably through electoral engagement or political activity through mainstream organizations, such as political parties. This, in turn, then erodes the overall legitimacy of representative institutions.

- Increasing participation divides: The problems of connection are exacerbated in areas of social deprivation and inequality, and hence, trust, knowledge, and engagement are declining most amongst the poorest. Additionally, many of these problems are more acute amongst younger people, raising fears of a generational switch-off from mainstream politics.

These factors could signal a potential change of direction from representation and representative politics towards forms of politics characterized by participatory decision-making (Baiocchi, 2005; Rios Insua, Kersten, Rios, \& Grima, 2008) and the direct engagement of citizens in the co-creation of policy (Cremer \& Mullenger, 2016; Fillmore-Patrick, 2013). Participatory decision-making in the form of budgeting has been demonstrated in the Brazilian municipality of Porto Alegre (Baiocchi, 2005; Wagle \& Shah, 2003), the city of New York in the USA (Su, 2017), and the Icelandic capital Reykjavik (Lackaff, 2016). In all three examples, citizens continuously participate in the decisionmaking process and are empowered to influence the outcome. The outcome of these examples has improved the quality of life for citizens in several areas. For instance, in the case of Porto Alegre, Wagle and Shah (2003, p. 3) identified that between 1989 and 1996 "the number of households with access to water services rose from $80 \%$ to $98 \%$; the percentage of the population served by the municipal sewage system rose from $46 \%$ to $85 \%$; the number of children enrolled in public schools doubled".

Further, examples that could be interpreted as co-creation are the Icelandic constitution (Fillmore-Patrick, 2013) and the European Cultural Foundation (EF) initiative entitled Build the City (Cremer \& Mullenger, 2016). The Icelandic constitution arose from the financial crisis of 2008, which led to massive protests in the country and consequently to the formation of a national assembly consisting of 1500 people. This assembly was tasked with the assignment of using a national online forum to deliberate and co-create a new constitution based on a set principles related to morality, justice, and democracy. Although the new constitution has not yet been enacted by parliament, it serves as an example of large-scale co-creation in practice (Fillmore-Patrick, 2013). Similarly, the Build the City initiative by the European Cultural Foundation (EF) has demonstrated the potential of co-creation to address urban challenges such as housing, the inclusion of migrants and refugees, and responsible public procurement. One example detailed in this initiative is the digital platform of SynAthina, which was created by the city of Athens to facilitate spontaneous solutions to urban problems and engage citizens in generating small-scale solutions for the city. The platform provides citizens with the possibility of connecting with the private sector, expertise, and local administration to develop public practices with the aim of modernizing local governance. The outcome of the project generated 500 activities by 120 citizen groups, ranging from an alternative guided tour to handmade pocket parks. Activities are evaluated each year, and the top ten activities are presented as transferable toolkits for other communities in Athens (Cremer \& Mullenger, 2016).

The emergence of ICTs, and notably social media platforms, has been seen by political representatives as offering the possibility of bridging the disconnect between themselves and their con- 
stituents (Hoff, 2004; Ward \& Lusoli, 2005). Despite the keen interest in ICTs for democratic purposes, skepticism remains that these alone will engage citizens in conventional representative politics. Early studies have indicated that ICTs are unlikely to stimulate people to participate in political processes due to a lack of interest or knowledge of politics (Norris, 2000; Ward, Gibson, \& Lusoli, 2003). However, subsequent research has argued otherwise, finding evidence concerning the use of social media to mobilize people to participate in political protests, such as the London riots in the UK, the Indignados in Spain, and Tahrir Square in Egypt (Castells et al., 2012; Mason, 2012).

While ICT-based solutions may have contributed to an increase in the quality of democratic processes, for example, by providing citizens with access to "tools for searching, selecting, and integrating the vast amounts of information held by the public administration as well as presenting the results in a form that can be readily used by individual citizens" (OECD, 2003, p. 15), their overall results and impact on democracy are much less obvious (ibid). One explanation for this could be that the abovementioned solutions have mainly been developed ad hoc to address particular issues or individual projects (Tomkova, 2009) and that the specific solutions have made limited improvements to the overall quality of democracy (OECD, 2003; Peña-López, 2011). Indeed, as Mulder (2014, p. 437) has argued, relatively little progress has occurred "to support the day-to-day issues of existing democratic processes". Given these mentioned concerns about representative democracy and the opportunities ICTs offer for citizens, it is feasible to contemplate that a different approach to democracy might be necessary in order for citizens to actively participate in democratic processes, engage in networks of communities, and continuously contribute to civil society based on their needs, interests, and wishes (Faraon et al., 2013).

To further explore the relationships between technology, democracy, and citizens, it may be possible to look at how each dimension shapes the other. Such research has been conducted within the contexts of technologically-deterministic and socio-constructivist studies. While technodeterministic studies have primarily investigated how technological functionalities and features contribute to social and institutional change (Layne \& Lee, 2001; West, 2004), socio-constructivist studies have followed the ideas of social determinism, namely that technology emerges from the interaction between social groups and in turn shapes organizational transformations (Bijker, Hughes, \& Pinch, 1987; Klein \& Kleinman, 2002). Rather than focusing on each of the mentioned relationships separately, the current article will focus attention on the relational interdependencies that in turn inform the outcome of previous relationships. Relational interdependencies have been perceived as the main benefit of actor-network theory (ANT) (Aanestad, 2003; Walsham, 1997), which focuses on the nature and effects of networks that connect human and non-human actors, their interests, needs, and motives. Based on previous considerations, this article adopts a sociotechnical approach and examines how the ANT framework with its theoretical underpinnings can contribute to advance the concept of co-creative media in the context of democratic engagement.

\subsection{Actor-Network Theory}

With the introduction of ANT, Latour (1987) argued that science and technology must be studied based on the dynamics of their interaction and continuously in relation to one another. Rather than contemplating the stability of their relationship, the focus should be on examining 
them in action and as an ongoing process. ANT has been used in traditional science and technology studies (STS) to examine the dichotomization of entities and modernist separations, such as subject/object, nature/culture, and mind/body. However, it has moved out of STS to concerns infused in everyday life, such as social, democratic, ecological, and political issues, where design and technology are an integral part (Storni, 2015). ANT has, since its introduction, been used as a theoretical framework for a wide range of disciplines, for example economics (Bledin \& Shewmake, 2004), geography (Rutherford \& Holmes, 2008), organizational studies (Fox, 2000), healthcare (Broer, Nieboer, \& Bal, 2010), information technology (Cordella, 2009; Quattrone \& Hopper, 2006), and design (Aanestad, 2003; Storni, Binder, Linde, \& Stuedah, 2015).

ANT could be interpreted as an intermediary between technologically-deterministic and socioconstructivist studies by avoiding the technology-society dualism and shifting attention to the processes that shape and reshape socio-technical networks (Bloomfield \& Vurdubakis, 1997; Knights, Coombs, \& Bloomfield, 1997). The term network, as Callon (1993, p. 263) defines it, is a "group of unspecified relationships among entities of which the nature itself is undetermined". The broad and general character of this definition becomes apparent when compared to established sociological definitions of a network: "a social network consists of a finite set or sets of actors and the relation or relations defined on them" (Wasserman \& Faust, 1994, p. 20). In ANT, a network is not limited to "social actors" or even actors. Latour (1996b) uses the term 'network' to describe society, not as two-dimensional (surface) or three-dimensional (sphere), but as a collective that consists of "nodes that have as many dimensions as they have connections" (Latour, 1996b, p. 370). In this sense, ANT does not view modern societies as being structured into different levels, categories, or systems, but instead recognizes them in terms of having a thread-like, veined, and stringy character (Latour, 1996b). Latour (2005) adopts the term collective in lieu of society since the latter, as it is conventionally understood, may imply "the existence of some transcendent entity that directs human action from outside" (Ritzer \& Stepnisky, 2018, p. 528).

ANT acknowledges the ability to act (e.g., to take action, stimulate change, make a difference) of both humans and non-humans, which is referred to as the principle of generalized symmetry (Latour, 1993). An actor or actant (to overcome the human connotation by the former), whether a human, a text, or a machine, is defined in ANT as "something that acts, or can literally be anything provided it is granted to be the source of action" (Latour, 1996b, p. 373). Actors or entities, as Law (1999, p. 3) puts it, "take their form and acquire their attributes as a result of their relations with other entities". Socio-technical relationships could, in this sense, be considered as a continuous series of interactions or associations in which entities are not predefined prior to being involved in particular relationships (Cordella \& Hesse, 2015). Latour's principle of irreduction posits that entities, assumed to be citizens, technological artifacts, or organizations, do not have a priori effects on their relationships; rather, the effects emerge as a consequence based on their interactions or associations in relational networks (Cordella, 2009; Latour, 1993).

Central to ANT is the way in which networks are formed through a process referred to as translation, which allows actors to build, maintain, and make changes to a network through the alignment of their interests (Callon, 1986). Alignment, in this sense, includes an open-ended collection of "things" to be aligned, for example "work-routines, incentive structures, training, information systems modules and organizational roles" (Monteiro, 2000, p. 72). It follows that there cannot be a top-down control of "things"; instead, a collection of diverse "things" is the achievement of bot- 
tom-up mobilization, which Latour (1996a, p. 86) emphasizes in his phrase "every day is a working day". The outcome of translation is a "heterogeneous network of aligned interests, including people, organizations, and standards" (Walsham \& Sahay, 1999, p. 42), which is formed through the construction of common meanings and continuous negotiations (Wolf, 2010). In Callon's conceptualization, the process of translation consists of four steps or moments: problematization, interessement, enrolment, and mobilization (Callon, 1986, p. 196).

The first, problematization, is concerned with describing the arrangement of relationships or alliances between actors, and in this way determining the identities and goals of those involved (ibid). Actors, in this sense, may not always reach their individual goals because of their respective obstacles. For this reason, they need to align their interests and coordinate with other actors by way of cooperation. This may establish them as the prime actors or, in ANT terminology, as an obligatory passage point (OPP) that mediates interactions between other actors in a network (ibid). Use of the term 'problematization' rather than 'problem' offers two advantages. Firstly, it suggests that the definition of a problem does not emerge solely from just a perspective but also from a performance. Secondly, problematization is not a fixed or static occurrence, but a recursive act taking place as a result of the dynamic practices that make up a problematization (Broer et al., 2010).

The second moment, called interessement, can be conceived as an activity that includes and excludes actors in a network by negotiating the terms or roles of their involvement (Callon, 1986). Various devices, for example technology, physical devices, political forces, or even textual content (Papadopoulos \& Wongkaew, 2008), could be used to enroll actors, strengthening the associations between them (Lowe, 1997) and supporting the structure of a network (Latour, 1990). Successful interessement results in enrolment in a network.

The third moment, i.e. enrolment, could be described as a set of "negotiations, trials of strength and tricks that accompany the interessements and enable them to succeed" (Callon, 1986, p. 212). In this moment, actors formally accept the roles that have been defined for them during interessement. Following successful negotiations between actors, an inscription emerges to prescribe a framework for possible action (Akrich, 1992). An inscription is "a process of creation of artifacts that would ensure the protection of certain interests" (Sarker, Sarker, \& Sidorova, 2006, p. 56) and could manifest as, for example, media, procedures, routines, rules, or work plans (Latour, 1990). Those with opposing interests, i.e. the non-cooperating actors, may have to yield if a large number of actors are enrolled in a network. Enrolment leads to the creation of a network of alliances and builds an agreement among differing actors (Alcouffe, Berland, \& Levant, 2008).

The fourth moment, mobilization, refers to where one or more prime actor(s) "borrows the force of the passive agents that it has enrolled by turning itself into their spokesman" (Law, 1986, p. 16). Spokespersons simplify networks by representing others' interests (who may or may not agree) and promoting a course of action (Ritzer, 2005). In doing so, a large number of actors within a network may emerge to support a proposed inscription, which could lead to black-boxing, meaning the broad acceptance of an inscription and the stability of its associated relationships. In spite of this, the possibility remains for those who will not follow their spokespersons to dispute or reject the proposed inscription (Rivera \& Cox, 2016) and challenge a network's spokesperson by questioning "the validity or reliability of the representation" (Ritzer, 2005, p. 3). When this occurs, as Callon (1986, p. 224) explains, "translation continues but the equilibrium has been modified [...] reality 
begins to fluctuate". Based on this definition, the process of translation is never concluded and is instead continuous.

The analytical framework of ANT provides a theoretical underpinning for studying the concept of co-creative media as an ongoing process of transformation in the context of democratic engagement. According to Lanzara (1999, p. 332), "systems and artifacts have been mainly looked at as 'closed boxes' [...] finished tools in the hands of the users". Instead of "opening the black box" to examine what made it stable, it is important to track "the process before the box actually gets closed" (ibid, p. 332), if indeed the box ever does get closed. The contribution of this article, namely the concept of co-creative media, adopts the theoretical resources offered by ANT and may be conceived as a recursive process of change that affects and is being affected by various actors, both humans and non-humans, for example citizens, technological artifacts, or organizations, within a collective of networked relationships. Because the concept is grounded on existing information and communication technologies and aims to facilitate democratic engagement, the following section will provide an analysis of publicly accessible socio-technical systems applicable for democratic engagement.

\subsection{Analysis of Socio-Technical Systems for Democratic Engagement}

A range of socio-technical systems were aggregated using Internet searches (using keywords such as "democratic engagement tools" and "democratic apps") and a list of active citizen engagement projects available at metagovernment.org (2015). These socio-technical systems can be rated against criteria that have emerged out of the conducted studies and existing research literature on democratic engagement, see Table 1 for an overview. These criteria are as follows: mobilization, collaboration, multilingualism, third-party adoptability, voting, scalability, integration of online content, and open source (independence from government and proprietorship).

Mobilization can be conceived of as an important phase in the democratic engagement process, as witnessed in various protests within the United Kingdom (e.g., the London riots), the Indignados in Spain, Tahrir Square in Egypt, Occupy Wall Street in New York, and the subsequent global Occupy Together movements during 2011 (Castells et al., 2012; Mason, 2012). These protests have in common the usage of events/groups features of various social media and smartphones as a means of mobilization, communication, and organization. Citizens mobilize themselves in an attempt to influence the existing distribution of power, or reactively organize themselves against unjust political, economic, or human rights conditions (Howard, Agarwal, \& Hussain, 2011; Lotan et al., 2011). However, mobilization itself does not result in change, but rather the process that follows mobilization. The term mobilization is used in ANT and refers to the prime actor(s) who "borrows the force of the passive agents that it has enrolled by turning itself into their spokesman" (Law, 1986, p. 16). This puts forward a view that could be associated with representative democracy and a top-down approach to governance. The concept of co-creative media builds on a participatory, bottom-up approach and, in contrast to the previous definition, defines mobilization as a "process by which the masses are gathered for involvement towards common interests and goals in issues or initiatives, without assuming a leader" (Faraon et al., 2013).

Collaboration could be perceived as a form of democracy where mobilized citizens combine their resources to achieve common interests (Kemmis \& McKinney, 2011). This has been demonstrated 
in existing examples such as wikis (e.g., Wikispaces, EditMe, Wikidot), document creation (e.g., Google Docs, Sync.in, Mindmeister, Docracy), and graphical visualization (e.g., Dabbleboard, CoSketch, Chartle). For such tools to serve democratic functions, it is necessary to ensure that their adoption does not marginalize any groups of citizens, that is, to acknowledge inclusiveness (Trechsel, 2007).

Multilingualism is an essential criterion due to the linguistic diversity within societies and the need to facilitate multilingual interaction among citizens. In an inclusive process, the availability of an accessibility platform in multiple languages is important in supporting understanding and consensus-seeking between citizens (Doerr, 2012). It is also necessary to provide the means for citizens to receive and communicate information with the support of a translation mechanism in the language-to-language sense, which should not be confused with Callon's (1986) concept of translation in ANT. Such a mechanism could be adapted using existing third-party services such as Google Translate, supplemented with functionality where citizens may contribute to improving the quality of the translation. Multilingualism can be designed into democratic innovations to remove or reduce modes of exclusions with regard to marginalized groups (Smith, 2013).

Third-party adoptability of digital technology using plugins/add-ons creates the possibility of integration of third-party services and functionality to address the needs, interests, and wishes of the different stakeholders in society. Such adoptability has the potential to offer citizens and their communities the possibility of designing, creating, modifying, and scaling ICT-supported solutions for democratic engagement. This could be accomplished by means of Open Application Programming Interfaces (Open APIs), which act as a bridge between disparate applications and have the potential to expand the reach of an organization. Open APIs are being offered by many corporations, for example, Google, Facebook, and Twitter, and provide developers with programmatic access to the content of proprietary software applications or web services for repurposing and contextualization based on the interests and needs of stakeholders (Yuanbo, 2017).

Voting is vital in a democratic society as it serves several different democratic functions (e.g., elections, decision-making). In the case of problematization, it may lead to a process of decisionmaking that can be determined by means of voting or deliberation. In the context of this article, voting refers to remote electronic voting via the Internet, where the casting of a secure and secret electronic ballot is carried out under the voter's sole influence (Dill \& Castro, 2008; Sanford \& Rose, 2007). Voting as decision-making creates empowerment for citizens, since it produces decisions. It also provides vital information about the strength of a decision by retaining and expressing dissent. Per contra, voting has a weakness in regards to acting as a function for communication and collective will formation, largely because it is not propositional. At best, voting can aggregate preferences within a structured agenda, unlike when deliberation is used as a choice for decisionmaking (Warren, 2012). Several solutions exist that could be used and adapted for the purposes of voting over the Internet. These solutions, as demonstrated for example in Estonia, include a combination of components such as an identity card, a smart card reader, a voting software for digitally signing the ballot, and a smartphone application to verify the submitted vote (Vassil, Solvak, Vinkel, Trechsel, \& Alvarez, 2016).

Scalability is a criterion for how effectively an ICT-supported solution for democratic engagement can, on the one hand, scale up in order to extend its capabilities to meet the needs, interests, and wishes of a broader public or increased requirements by its stakeholders (Zissis, Lekkas, \& 
Papadopoelia, 2009). On the other hand, scaling down may be required to support microdemocracies (e.g. housing cooperatives, sport clubs) (Faraon et al., 2013; Rothstein, 2013). This requirement needs to be supported by the infrastructure of the environment in order to serve citizens' needs and satisfy the demands of a continuously expanding group of citizens, i.e. an increasing interest from citizens in engaging in politics and decisions that affect them (Meneklis, Kaliontzoglou, Polemi, \& Douligeris, 2005). Scalability can be accomplished along five dimensions: administrative, functional, geographic, load, and generation. The administrative refers to an increasing number of users sharing a single distributed system; the functional dimension is concerned with the ability to add, modify, or delete functionality with minimal effort; the geo-graphic dimension is related to maintaining performance regardless of expansion from a local to a more distributed geographic area; the load dimension involves the ability of a distributed system to accommodate a higher number of inputs or requests; and the generation dimension involves scaling up a system by using components from different vendors (El-Rewini \& Abd-El-Barr, 2005).

The integration of online content is a criterion that allows the dissemination of information and news to citizens so they can be sufficiently informed to make educated and reasoned decisions. Such content can be created, modified, and shared by citizens themselves as is typically observed in virtual social networks. However, it can also be journalistically edited content that is distributed by online news outlets (Faraon et al., 2014). An understanding of the influence of different types of content on our attitudes and behavior may have implications for the design of socio-technical systems for democratic engagement. Integration of online content is possible through news outlets such as CNN, BBC, or the New York Times, which provide a web feed via an open standard referred to as Real Simple Syndication (RSS) (Shumow \& Vigon, 2016). In addition, content curation tools such as HubSpot (hubspot.com) or Curata (curata.com) offer the possibility of creating and filling a social feed with content based on interest.

Open source, broadly defined as the access to and free distribution of software (DiBona, Ockman, \& Stone, 1999), is the criterion that promotes the independence of both proprietorship and government control. Independence of proprietorship may contribute to the transparency, security, and accountability of the development of technology. This approach could increase the trust of a community, where grassroots developers within communities can reuse and repurpose code. By adopting transparency through open source, anyone with sufficient competency can access, improve, and use the technology to suit specific needs. Security is greatly improved by allowing developers to seek out flaws rather than attempting to conceal any security defects (Schneier, 1996). Transparency can be achieved through the emerging blockchain technology, which provides the necessary means of tracking changes in ICT-supported solutions and holding those participating accountable (Boucher, 2016). In practice, an open source approach has proven to be successful in empowering citizens, with examples including My Society (mysociety.org, open source tools for civic engagement), Poplus (poplus.org, a tool for sharing software for civic and democratic purposes), and the Open Institute in Kenya (openinstitute.com, in which citizens propose initiatives and develop initiatives/projects). By providing technology-driven tools and prototypes to communities, individuals can participate in creating new solutions and take part in decisions that directly affect their lives. Such tools can be published to and accessed from repository hosting services such as GitHub (github.com), which has contributed to collaborative functions such as code sharing, task management tools, and publishing services. Furthermore, open source has shown its 
usefulness by providing citizens with the means to circumvent censor-ship by using tools such as Freegate, GTunnel, and Ultrasurf. The matrix, as presented in Table 1, serves the purpose of choosing services for a closer analysis of their usefulness for democratic engagement. In order to identify examples for analysis, those services that fulfilled most of the previously mentioned criteria were selected, namely Democracy-OS (democracyos.org) and Facebook (facebook.com).

DemocracyOS is an open source socio-technical system for online deliberation and decisionmaking. It was initiated by the Net Democracy Foundation and developed by a group of activists, entrepreneurs, students, and hackers in April 2012. The motivation for developing the platform was to support a continuous interaction between citizens, government, and politics. In terms of the mentioned criteria, DemocracyOS fulfills those of collaboration, multilingualism, voting, integration of online content, and open-source (independence from government and proprietorship), which will be examined more closely in the following sections. With regard to multilingualism, the platform is available in 15 languages and has been widely adopted in countries such as Tunisia (to debate the national constitution), Mexico (to develop its open government policy), and Kenya (by a parliamentary member to consult his constituency), among others. It allows participants to initiate, debate, and vote on proposals. Collaboration and deliberation occur in a section for each proposal called "arguments". In this section, participants present, debate, and improve arguments with each other. Each argument can be replied to and can also be voted up or down to filter out noise from trolls, i.e. those who sow discord. Voting does not only occur for each argument, but also for the entire proposal using one of the following options: yea, abstain, or nay. Each proposal can integrate online content such as photos, pdf files, links to Twitter usernames, hashtags, and YouTube clips. The platform is published as open source under the MIT license and is accessible on GitHub, a repository for publishing web projects and version control.

While DemocracyOS fulfills a number of the criteria discussed above, it falls short in terms mobilization, third-party adoptability, and scalability. With regards to mobilization, the platform does not support the functionality to create events or petitions so that citizens can mobilize themselves behind a cause by means of mass invitation through social networks and e-mail. Moreover, the platform does not support third-party functionalities such as registration and social login using OpenID providers (e.g. Google, Yahoo!, AOL, WordPress) or social network providers (e.g. Facebook, Twitter). Other lacking functionalities include the dissemination of content through Facebook's Like and Send buttons or Twitter's Tweet button, among others. Finally, with regards to scalability, DemocracyOS does not provide the necessary means to scale the platform up or down to address the wishes, needs, and goals of citizens.

We now turn our focus to Facebook, which is a private company founded by Mark Zuckerberg in 2004. During the Arab Spring, it was clear that Facebook played a central role in mobilizing people during the uprisings, mainly through the creation of events on Facebook and inviting people to attend these physical events. While Facebook was not specifically designed to facilitate and support democratic engagement, it has shown its usefulness by allowing people to collaborate on an array of issues in different groups, by creating specific apps, or through private messaging. Facebook supports the criteria of multilingualism, offering over 70 languages, and has a functionality that enables users to translate text on the platform. Furthermore, Facebook provides support for third-party adoptability and allows third parties to integrate their content directly into the platform. 
Table 1: Comparison matrix of socio-technical systems for democratic engagement. Asterisk $\left(^{*}\right)$ refers to Electronic Infrastructure for Political Work.

\begin{tabular}{|c|c|c|c|c|c|c|c|c|c|}
\hline \multirow[b]{2}{*}{$\begin{array}{l}\text { Socio-technical } \\
\text { systems }\end{array}$} & \multicolumn{9}{|c|}{ Criteria } \\
\hline & Mobilization & Collaboration & Multilingualism & $\begin{array}{l}\text { Third party } \\
\text { adoptability }\end{array}$ & Voting & Scalability & $\begin{array}{c}\text { Integration } \\
\text { of online } \\
\text { content }\end{array}$ & $\begin{array}{c}\text { Open source } \\
\text { (independence } \\
\text { of government) }\end{array}$ & $\begin{array}{c}\text { Open source } \\
\text { (independence of } \\
\text { proprietorship) }\end{array}$ \\
\hline Agora Voting & & & $\mathrm{x}$ & & $\mathrm{x}$ & $\mathrm{x}$ & & $\mathrm{x}$ & $x$ \\
\hline Airesis & & & $\mathrm{x}$ & $\mathrm{x}$ & $\mathrm{x}$ & & & $\mathrm{x}$ & $\mathrm{x}$ \\
\hline Deebase & & $x$ & & $\mathrm{x}$ & $\mathrm{x}$ & $x$ & & & \\
\hline Deme & & $x$ & & & & & & $x$ & $x$ \\
\hline DemocracyLab & & $\mathrm{x}$ & & & & & & $\mathrm{x}$ & $\mathrm{x}$ \\
\hline DemocracyOS & & $\mathrm{x}$ & $\mathrm{x}$ & & $\mathrm{x}$ & & $\mathrm{x}$ & $x$ & $x$ \\
\hline DemTools & $\mathrm{x}$ & & & & $\mathrm{x}$ & & $\mathrm{x}$ & $\mathrm{x}$ & $\mathrm{x}$ \\
\hline Echo.to & & $\mathrm{x}$ & $\mathrm{x}$ & $\mathrm{x}$ & & & & $x$ & $\mathrm{x}$ \\
\hline EIPW* & $\mathrm{x}$ & $x$ & $\mathrm{x}$ & & $\mathrm{x}$ & $\mathrm{x}$ & & & \\
\hline Facebook & $\mathrm{x}$ & $\mathrm{x}$ & $\mathrm{x}$ & $\mathrm{x}$ & & $\mathrm{x}$ & $\mathrm{x}$ & & \\
\hline Leading Boards & & $\mathrm{x}$ & $\mathrm{x}$ & & $\mathrm{x}$ & & & & \\
\hline LiquidFeedback & $\mathrm{x}$ & $x$ & & & $x$ & & & $x$ & $x$ \\
\hline Loomio & & $x$ & & & $x$ & & & $x$ & $x$ \\
\hline NationBuilder & $\mathrm{x}$ & & & $\mathrm{x}$ & $\mathrm{x}$ & $x$ & $x$ & & \\
\hline Openpolitics.ca & & $\mathrm{x}$ & & & & & $\mathrm{x}$ & $\mathrm{x}$ & $\mathrm{x}$ \\
\hline Twitter & $\mathrm{x}$ & & $\mathrm{x}$ & $\mathrm{x}$ & & $x$ & $x$ & & \\
\hline Vilfredo & $x$ & $x$ & & & $\mathrm{x}$ & & & $x$ & $x$ \\
\hline VirtualPol & & $x$ & & $x$ & $\mathrm{x}$ & & & $\mathrm{x}$ & $\mathrm{x}$ \\
\hline Votetocracy & $x$ & $x$ & & & $x$ & & & & \\
\hline Votorola & & $\mathrm{x}$ & & & $\mathrm{x}$ & $x$ & & $\mathrm{x}$ & $\mathrm{x}$ \\
\hline Wasa2il & & & $\mathrm{x}$ & & $\mathrm{x}$ & & & $x$ & $\mathrm{x}$ \\
\hline YouTube & $\mathrm{x}$ & & $\mathrm{x}$ & & & & $\mathrm{x}$ & & \\
\hline
\end{tabular}


Since developers can create their specific applications, they can utilize Facebook's various application programming interfaces (APIs) to build applications that are scalable over time. Finally, Facebook supports the integration of online content, whereby users can share and spread external links on the platform with other users.

However, despite Facebook fulfilling a number of the mentioned criteria, it falls short on the following: voting, open source (independence from government), and open source (independence from proprietorship). While Facebook supports voting in terms of polls, it does not support localized voting mechanisms that offer the security and anonymity required to conduct both small and large-scale general elections. The criteria listed above are closely connected with the fact that this is a social platform that is run by a private company, which creates concerns related to privacy, transparency, and data ownership (Smith, Bossen, \& Kanstrup, 2017). Each of these criteria is important in the democratic engagement process.

In summary, and in the context of democratic engagement, the examples given above of sociotechnical systems, DemocracyOS and Facebook, have shown their usefulness in certain ways but are limited in others. While some concepts from ANT can be found within Facebook and DemocracyOS, for example problematization and network, it can only be hypothesized as to whether they were intentionally designed with a theoretical framework in mind. The concept of co-creative media integrates the theoretical concepts of ANT, and aims to fulfill the criteria identified in Table 1 to support the democratic engagement of citizens by facilitating participatory and co-creative processes.

\section{Methodological Approach}

\subsection{Concept-Driven Design Research}

Several research approaches are available when designing ICTs for democratic engagement, for example, user-centered design, participatory design, contextual design, activity theory, and ethnographically informed systems design (for overviews, see Carroll, 2003; Kaptelinin \& Nardi, 2006; Rogers, 2004). Stolterman and Wiberg (2010) have argued that the objectives of most of these approaches "are built on the assumption that a suitable design proposal is to be grounded or even 'found' through careful analysis of an existing situation" (ibid, p. 97). While these approaches have proven to be successful in the design of digital artifacts for specific contexts or existing situations, they are not always "suitable when the purpose is to develop more conceptual and theoretical contributions" (ibid, p. 98). Based on this reasoning, Stolterman and Wiberg proposed a new approach, namely concept-driven design research, which is explorative and aims to widen the body of theory and knowledge (see further discussion by Weick (1989)).

Concept-driven design research can be understood as being rooted in futuristic use scenarios and theory, rather than in "careful studies of present user conditions and situations" (Stolterman \& Wiberg, 2010, p. 97), as often reflected in conventional HCI research. The concept-driven approach aims to improve theoretical concepts and manifest "visionary theoretical ideas in concrete designs" (ibid, p. 97). Indeed, as Stolterman and Wiberg argue, a good concept design manifests "both something that is theoretically relevant and new as well as paying tribute to existing established 
theoretical concepts" (ibid, p. 105). The authors explicitly define the research approach as including the following steps (ibid, p. 98):

1. The point of departure is conceptual/theoretical rather than empirical.

2. The research furthers conceptual and theoretical explorations through hands-on design and development of artifacts.

3. The end result - that is, the final design - is optimized in relation to a specific idea, concept, or theory rather than a specific problem, user, or a particular use context.

Each of these steps will be described in the next section, and they are discussed in relation to the resulting concept of co-creative media. The process for the concept-driven research approach is illustrated in Figure 1, adopted from Stolterman and Wiberg (2010, p. 101).

Figure 1: Shown here is the process of the concept-driven design research approach in relation to theory and use situation.

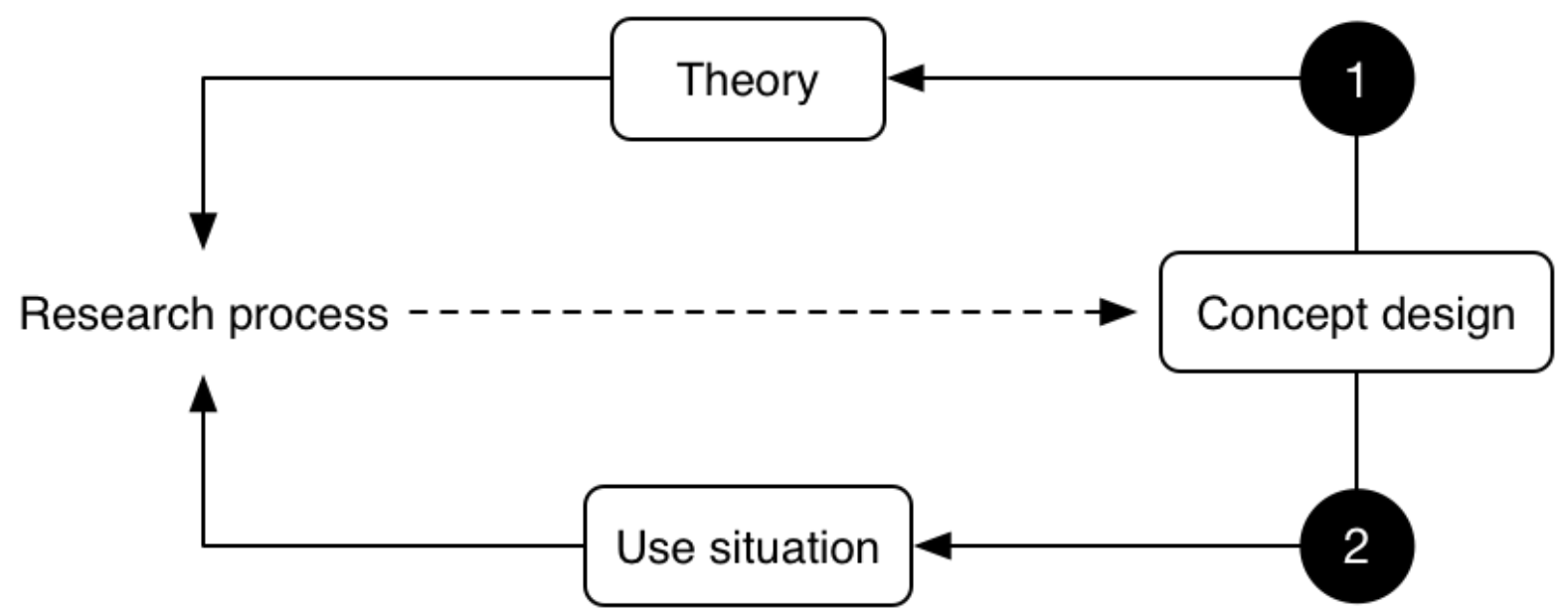

While the research approaches mentioned above aim primarily to produce a concept that supports the use situation (Arrow 2), the primary goal of the concept-driven design research approach is to support theoretical development (Arrow 1) (ibid, p. 100). The overall purpose of the concept-driven approach is knowledge production, and the question of whether this can "lead to improvements of a situation is of lesser interest, or maybe even no interest at all" (ibid, 2010, p. 101). Several studies have adopted the concept-driven design research approach, and while they have typically resulted in a prototype (Eliasson, 2013; Johansson, Lassinantti, \& Wiberg, 2015; Johansson \& Wiberg, 2012), others have concluded in concept designs (Nazzi, Bagalkot, Nagargoje, \& Sokoler, 2012).

Concept-driven design research includes seven methodological activities: concept generation, concept exploration, internal concept critique, design of artifacts, external design critique, concept revisited, and finally concept contextualization. The first activity, concept generation, involves the production of new concepts based on previous theoretical work. While such concepts involve a process that cannot be prescribed, it may be conducted by "working with associations, metaphors, conflicting or opposing theoretical concepts, theories from other design fields, and historical or other paradig- 
matic examples" (Stolterman \& Wiberg, 2010, p. 110). The second activity, concept exploration, includes a process in which the researcher(s) works hands-on with materials and content, in order to create models. The purpose of this activity is to explore new design spaces that lead to new ideas. The third activity, internal concept critique, refers to a process in which the design and associated concepts are related to an established theoretical foundation. Three determinants define the success of this activity: "(a) the uniqueness of the chosen core concepts, (b) to what extent the concepts relate to existing theory, and (c) how well these concepts can be clearly expressed in a concrete design" (ibid, p. 100). The fourth activity, design of artifacts, refers to a process in which the design concept is manifested in the form of a concrete artifact. This process thus becomes "part of the design process and of the theoretical development." (ibid, p. 111) The fifth activity, external design critique, refers to a process whereby the idea, the concept, and associated theoretical principles are evaluated. As Stolterman and Wiberg argue, "this critique is an intellectual process of validating the conceptual and theoretical assumptions embodied in the manifested design" (ibid, p. 111). The sixth activity, concept revisited, relates to the critique and involves a step where the concept is revisited and revised. The critique from previous activity serves the purpose of guiding and furthering the design. The seventh activity, concept contextualization, draws on previous activities and requires that the work is related and valued "against the current body of concepts and theory in the field" (ibid, p. 111). In the current work, a decision was made to follow the abovementioned activities with a focus on theoretical and empirical advancements in order to further the concept of cocreative media. The empirical dimension necessitated an adapted process of concept-driven design, which is described in the next section.

With the research question in mind (How can the concept of co-creative media be furthered both theoretically and empirically to facilitate democratic engagement by citizens?), the conceptdriven design research approach was used in order to make theoretical contributions that are, in turn, manifested by means of concept designs. The contributions made are in the form of theoretical explorations (Faraon et al., 2011; Faraon et al., 2013), empirical studies (Faraon et al., 2015; Faraon et al., 2014), and concept designs (Faraon et al., 2013) as described in Chapter 4. In the following section, an adapted process of concept-driven design research is described in relation to the elaboration of the concept of co-creative media, in which the results of conducted studies theoretically underpin and empirically inform the concept.

\subsection{Application of Concept-Driven Design Research}

The design research process in this article could be described as an iterative process between theory and use situation, which informs and furthers the concept design. As proposed by Stolterman and Wiberg (2010), the concept-driven design research approach focuses on theoretical advancements that are simultaneously design- and concept-oriented. These advancements were made in the first (Faraon et al., 2013) and fourth studies (Faraon et al., 2011). In addition, the second and third studies comprised empirical investigations of established theories with "the overall aim of improving and widening the range of theory and knowledge" (Stolterman \& Wiberg, 2010, p. 102). Stolterman and Wiberg also argued that research with the aim of improving a use situation will "be evaluated in relation to how well the result resolves an unwanted situation and creates a desired one" (ibid, p. 101). However, research aiming at theoretical advancement will have a dif- 
ferent measure of success, namely "whether or not the research leads to improvement of theoretical concepts" (ibid, p. 101). Whether such theoretical improvements advance a current situation is of "lesser interest, or maybe even of no interest at all" (ibid, p. 101).

The implementation of the concept-driven design research approach in this article takes into account the significance of the use situation. It then is implemented by means of empirical studies to elaborate theoretical concepts of established theories that can inform and further the concept of cocreative media. The present research process adopts the use situation as a pointer to the events involving participatory action: using Internet voting as a decision-making mechanism (Faraon et al., 2015) and using online content for participatory purposes (Faraon et al., 2014). The aim of this is to relate the theoretical advancement of concepts related to these participatory actions, and at the same time to empirically inform the concept of co-creative media. This approach can be compared to that of Johansson and Wiberg (2012, p. 25), who used empirical data to improve a concept. Figure 2 outlines the relationship between the concept-driven design research approach and the four conducted studies, resulting in the concept of co-creative media.

Figure 2: Below is the adapted version of the concept-driven design research approach as presented by Stolterman and Wiberg (2010, p. 101), mapping the four conducted studies to theory and use situation. The use situation in the current article is implemented by means of empirical studies and points to an event of participatory action.

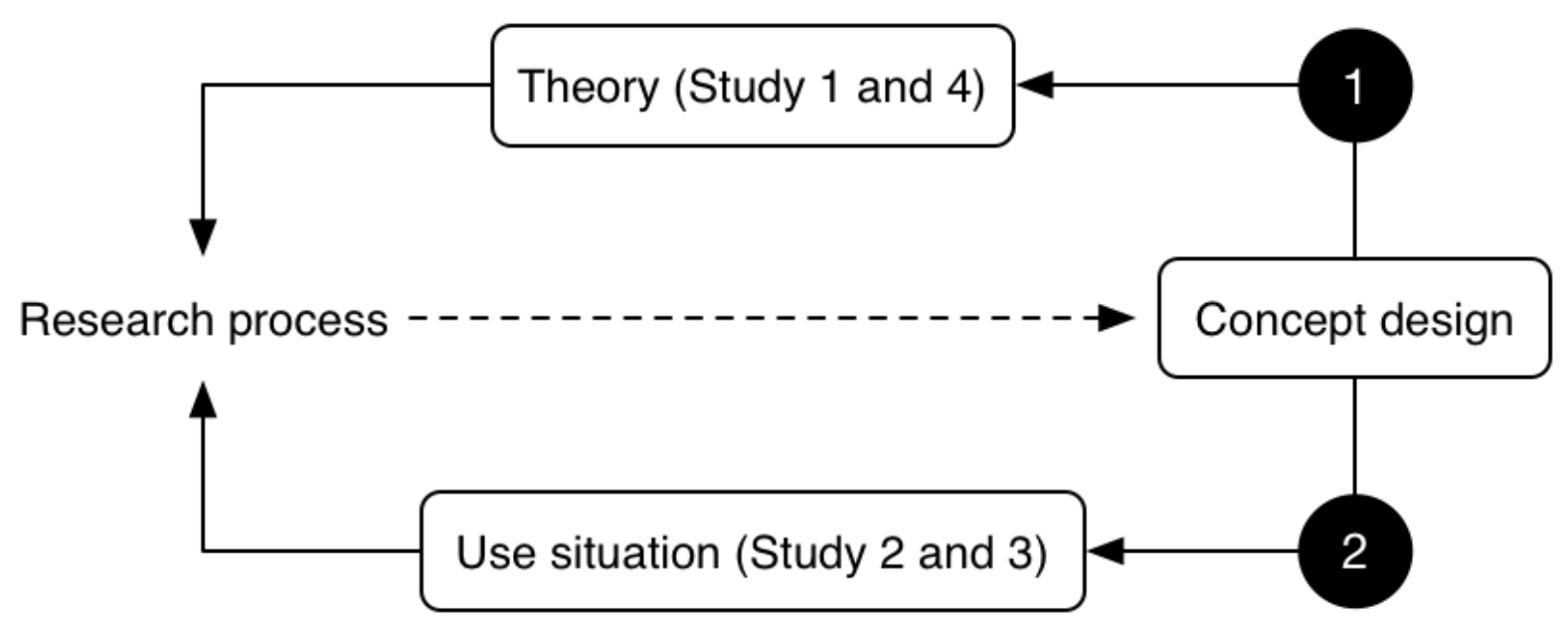

The four research studies form an interconnected investigation into the concept of co-creative media. The methodological activities of concept generation, concept exploration, internal concept critique, and design of artifacts were conducted in the first study, which served as the starting point for the evolution of co-creative media (Faraon et al., 2013), see Figure 3.

While the first study contributed with valuable theoretical and conceptual insights, the use of both theoretical and empirical investigations was relevant in furthering the concept of co-creative media. Based on the results of the first study, three research questions emerged that were examined in the second, third, and fourth studies. The research process adopted these theoretical and empirical studies as an external design critique to evaluate aspects of the concept and its associated theoretical principles. These studies were related to the use of Internet voting (Faraon et al., 2015), 
the influence of online information on political attitudes and voting behavior (Faraon et al., 2014), and the ways in which censorship could be circumvented (Faraon et al., 2011).

The second study explored the use of Internet voting and how it can be useful in supporting democratic engagement and aiding the mobilization of crowds behind political issues and campaigns (Faraon et al., 2015). The results revealed that participants were positive towards using Internet voting for political participation but skeptical about solving related security issues. Based on these results, it was concluded that Internet voting has the potential to facilitate continuous democratic engagement by citizens in decision-making processes, if the related security issues can be resolved.

Figure 3: Here is an abstract overview of co-creative media in the form of a design artifact depicting the path of an individual discovering an issue, then towards becoming engaged, and finally contributing to the process of creating a "solution" to this issue. The process is reflected along three paths of engagement and will be further described in the next section: (1) invitation; (2) community building; and finally (3) consensus-seeking.

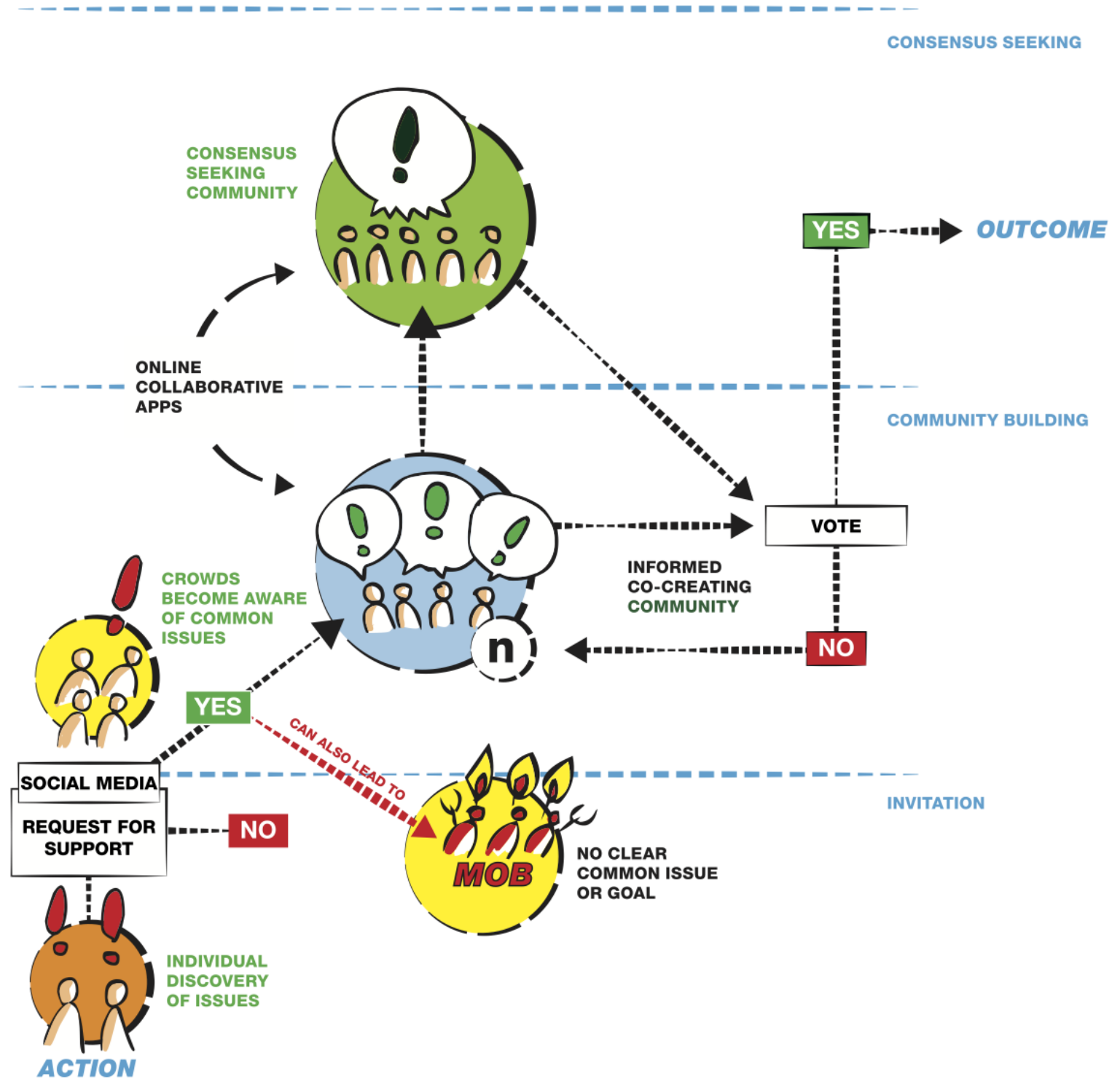


The third study examined how online content, as conveyed by online news versus correspondent communication via social media platforms, influences explicit and implicit attitudes and voting behavior (Faraon et al., 2014). The results showed that online news had a significant influence on both explicit and implicit attitudes, while social media platforms did not. In addition, the findings indicated that negative information had a stronger influence than positive, especially if information emanated from online news. Altogether, the results provide insights that need to be carefully considered regarding the design and presentation of information within the concept of cocreative media. Finally, the data suggest that unfavorable information, independent of the media used and when mediated through explicit attitudes, increases the chance of switching sides in terms of voting. The fourth study reviewed research on circumvention media. It concluded with theoretical insights into how various technologies could be repurposed to develop novel crossmedia services to support the free flow of information under conditions of censorship (Faraon et al., 2011).

In addition to the results from these four studies, this article adopts theoretical concepts from ANT and the criteria identified in the analysis of socio-technical systems for democratic engagement. With regards to ANT, theoretical concepts such as the actor/actants, relational network, collective, translation with its four moments (problematization, interessement, enrolment, and mobilization), alignment, spokesperson, obligatory passage point (OPP), inscription, and black-boxing were used to highlight the complexity and dynamic nature of the concept of co-creative media. The criteria identified in the analysis of socio-technical systems were adopted to theoretically underpin the concept in terms of its processes, functionalities, and characteristics. The identified criteria are mobilization, collaboration, multilingualism, third-party adaptability, voting, scalability, integration of online content, and open source (independence of government and proprietorship). The criteria for voting and the integration of online content were examined in the second (Faraon et al., 2015) and third studies (Faraon et al., 2014), respectively.

The results from the four studies, the theoretical underpinnings of ANT, and the criteria identified in the analysis of existing socio-technical systems were utilized in the concept-driven research process. The purpose of this was to further the concept of co-creative media in the context of democratic engagement beyond that presented in the first study. Based on these considerations and following the remaining methodological activities in the concept-driven design process, the concept of co-creative media was revisited and contextualized, as explained in the following section.

\section{Elaborating the Concept of Co-Creative Media}

The concept of co-creative media in this article was informed and contextualized by the theoretical concepts of ANT, the results of the four conducted studies, and the criteria identified in the analysis of existing socio-technical systems for democratic engagement.

Due to the dynamic nature of the concept of co-creative media, it is necessary to describe the process of engagement in terms of instantiations or iterations pursued by actors in a collective of networked relationships. The arrows indicate possible sequences that are at the same time instantiations of the co-creation process. The following will provide a more detailed description of a possible instantiation of the concept of co-creative media, as illustrated in Figure 4. In line with ANT, it is important to note that the following description is not assumed to be linear or hierarchical, but 
instead fibrous or stringy. This means that different processes, for example collaboration and consensus-seeking, could occur on different paths. The following will describe a possible co-creation process, which is associated with Callon's (Callon, 1986) translation process and its four moments of problematization, interessement, enrolment, and mobilization.

Figure 4: This is an example of an instantiation of the concept of co-creative media. Depicted is a flow process that may begin with citizens discovering issues or taking proactive initiatives, and then moving towards constructive and co-creative outcomes.

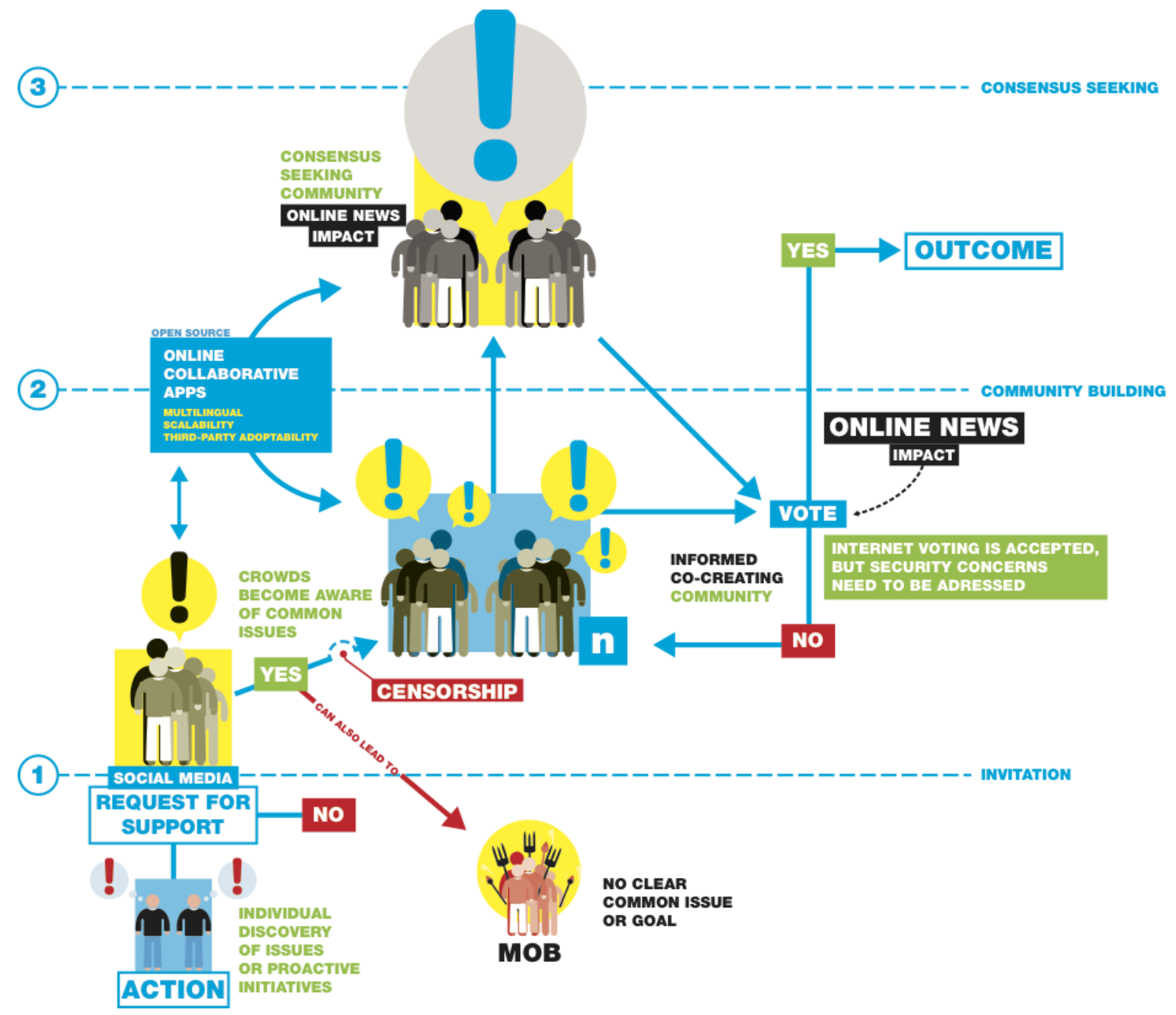

At the outset of the co-creation process, as indicated by the first path and corresponding to ANT's moment of problematization, is an action taken to address events whereby actors discover issues or take proactive initiatives. As suggested by Faraon et al. (2013), such processes may include mobilization, collaboration, consensus-seeking, and negotiation. They can occur in contexts that are dynamic and can be revised based on needs, interests, and wishes. To gain support for issues or initiatives, actors can utilize social media by inviting others, mobilizing support, and creating awareness. While such support could lead to the formation of a community that shares common goals and interests, it is also possible that this support could lead to a crowd with no clear 
common issue or goal (Faraon et al., 2013). In certain circumstances, where the flow of information is constrained or censored, it is necessary to develop and adopt cross-media services to circumvent censorship (Faraon et al., 2011). Existing tools such as Freegate, GTunnel, and Ultrasurf could be integrated and offered to bypass censorship.

By pursuing the second path, analogous to ANT's moment of interessement, a crowd of actors with shared common goals and interests can over time become increasingly aware of the identified issues or the initiatives, and therefore, start to establish a sense of community or a collective of networked relationships working towards constructive and co-creative outcomes (Faraon et al., 2013). To support constructive co-creation processes in a community, an array of open source applications could be made available under the umbrella of co-creative media for collaboration purposes. Applying an open source approach provides actors and communities with the freedom to tailor applications based on their needs and wishes. Ideally, the characteristics of such applications would include multilingualism and scalability, in order to overcome language barriers, promote diversity, and accommodate the potential growth of a community.

Furthermore, the concept of co-creative media supports the integration of third-party services to address the needs of different stakeholders. In practical terms, this could be achieved by means of Open Application Programming Interfaces (Open APIs) (Yuanbo, 2017). This integration could offer actors or their communities the ability to design, create, modify, and scale ICT-supported solutions for democratic engagement based on their needs. As a community becomes informed of certain issues or initiatives, the alignment of shared goals and interests can be articulated or manifested in the form of joint efforts, or in ANT terminology, inscriptions such as plans, proposals, strategies, budgets, designs, and other types of ventures within a community.

Upon the completion of joint efforts within a community, additional processes such as consensus-seeking and negotiations may be needed to resolve potential disagreements. This corresponds to the third path and ANT's moment of enrolment. This is where the means of consensus-seeking and negotiations may include mutual efforts of persuasion by actors within a community, for example by integrating content from online news outlets (Faraon et al., 2014) through the open standard of RSS or by adopting content curation tools (e.g., HubSpot, Curata). In the case of disagreements (corresponding to ANT's moment of mobilization but without necessarily using spokespersons as an obligatory passage point (OPP)), a mechanism may be provided that supports actors or a community by splitting the joint efforts into an unlimited number of branches $(n)$, thus allowing them to pursue a parallel evolution of co-creation. This allows the process of co-creation, or translation, to be continued until the joint efforts have been black-boxed, i.e., a broad acceptance of them is reached.

In certain circumstances, for instance in the case of citizen initiatives such as those allowed by the European Union (ec.europa.eu/citizens-initiative/) or under Finnish legislation (vrk.fi/en/finnish-citizens-initiative), an Internet voting procedure could be required to reach legally-binding agreements. Internet voting also has the potential to be widely used in citizens' continuous decision-making if security concerns are rigorously addressed (Faraon et al., 2015). As indicated on the third path in terms of outcome, joint efforts in some cases result in explicit, unanimous support, while in other cases the process of co-creation is more important than the actual result. 


\section{Conclusion}

The purpose of this article is to theoretically and empirically further the concept of co-creative media in order to facilitate democratic engagement by citizens. Contemporary examples of participatory, citizen projects aimed at democratic engagement, for example the Icelandic constitution (Fillmore-Patrick, 2013), the participatory budgeting of the Brazilian municipality of Porto Alegre (Baiocchi, 2005), and the European Cultural Foundation (ECF) initiative Build the City (Cremer \& Mullenger, 2016), could be interpreted as potential instances of co-creation. To further facilitate and support co-creation aimed at democratic engagement, the current article adopts the conceptdriven design research approach of Stolterman and Wiberg (2010) to advance the concept of cocreative media.

The present work demonstrates how the concept-driven design research approach can be implemented to conceptualize, theoretically anchor, and empirically inform a concept design. This was achieved through conceptual explorations, theoretical underpinnings, and empirical investigations. To address the research question, the theoretical underpinnings of ANT, the results of the four conducted studies, and the criteria identified in the analysis of existing socio-technical systems for democratic engagement were utilized in the concept-driven process, which was then used to expound upon and further the concept of co-creative media. With certain limitations, this study has illustrated the potential of applying an empirical perspective to design research with the purpose of making theoretical advancements in a concept design while utilizing empirical data to optimize it.

The co-creative media proposed here may provide citizens with a different approach to democracy, along with the ability to contribute to the collective intelligence and expertise in society. The possible implications of this include creating, developing, and strengthening partnerships between communities and local services, extending digital skills in society through community-engaged practitioners, and coordinating large-scale consensus on policy issues. Co-creative media in the form outlined in this article have the potential to broaden the democratic engagement of citizens by means of creating virtual spaces in which new ideas, initiatives, knowledge, and solutions can emerge.

As a concluding remark, future work could use the concept of co-creative media as a basis for further theoretical reflections on the complex nature of the introduction of ICTs for democratic engagement in society. These reflections may contribute to widening the body of knowledge in design research as well as help in supporting future participatory design processes where relevant stake-holders collectively contribute to the practical implementation and evaluation of co-creative media.

\section{References}

Aanestad, M. (2003). The camera as an actor: Design-in-use of telemedicine infrastructure in surgery. Computer Supported Cooperative Work, 12(1), 1-20.

Akrich, M. (1992). The de-scription of technical objects. In W. E. Bijker \& J. Law (Eds.), Shaping technology / building society: Studies in sociotechnical change (pp. 205-224). Cambridge, MA: MIT Press. 
Alcouffe, S., Berland, N., \& Levant, Y. (2008). Actor-networks and the diffusion of management accounting innovations: A comparative study. Management Accounting Research, 19(1), 1-17.

Baiocchi, G. (2005). Militants and citizens: The politics of participatory democracy in Porto Alegre. Stanford: Stanford University Press.

Bijker, W. E., Hughes, T. P., \& Pinch, T. J. (1987). The social construction of technological systems: New directions in the sociology and history of technology. Cambridge, MA: MIT Press.

Bledin, J., \& Shewmake, S. (2004). Research programs, model-building and actor-network-theory: Reassessing the case of the Leontief Paradox. Journal of Economic Methodology, 11(4), 455-476.

Bloomfield, B., \& Vurdubakis, T. (1997). Paper traces: Inscribing organization and information technology. In B. Bloomfield, R. Coombs, D. Knights, \& D. Littler (Eds.), Information technology and organization. Oxford: Oxford University Press.

Boucher, P. (2016). What if blockchain technology revolutionised voting? Retrieved from http:// www.europarl.europa.eu/RegData/etudes/ATAG/2016/581918/EPRS_ATA\%282016\%29581918_E N.pdf

Broer, T., Nieboer, A. P., \& Bal, R. A. (2010). Opening the black box of quality improvement collaboratives: An actor-network theory approach. BMC Health Services Research, 10(265), 1-9.

Callon, M. (1986). Some elements of a sociology of translation: Domestication of the scallops and the fishermen of St Brieuc Bay. In J. Law (Ed.), Power, action and belief: A new sociology of knowledge (pp. 196-233). London: Routledge \& Kegan Paul.

Callon, M. (1993). Variety and irreversibility in networks of technique conception and adoption. In D. Foray \& C. Freemann (Eds.), Technology and the wealth of nations: Dynamics of constructed advantage (pp. 232268). London, New York: Pinter.

Carroll, J. M. (2003). HCI models, theories, and frameworks toward a multidisciplinary science. San Francisco, CA: Morgan Kaufmann.

Castells, M., Caraca, J., \& Cardoso, G. (2012). Aftermath: The cultures of the economic crisis. Oxford: Oxford University Press.

Cordella, A. (2009). Information infrastructure: An actor-network perspective. International Journal of Actor Network Theory and Technological Innovation, 2(1), 27-53.

Cordella, A., \& Hesse, J. (2015). E-government in the making: an actor network perspective. Transforming Government: People, Process and Policy, 9(1), 104-125.

Cremer, M., \& Mullenger, N. (2016). Build the City: How people are changing their cities. Retrieved from http://www.culturalfoundation.eu/library/build-the-city-magazine

Dalton, R. (2004). Democratic challenges democratic choices: The erosion of political support in advanced industrial democracies. New York: Oxford University Press.

Diamond, L. (2015). Facing up to the democratic recession. Journal of Democracy, 26(1), 141-155.

DiBona, C., Ockman, S., \& Stone, M. (1999). Open sources: Voices from the open source revolution. Sebastopol, CA: O'Reilly and Associates. 
Dill, D. L., \& Castro, D. (2008). The U.S. should ban paperless electronic voting machines. Communications of the ACM, 51(10), 29-33.

Doerr, N. (2012). Translating democracy: How activists in the european social forum practice multilingual deliberation. European Political Science Review, 4(3), 1-24.

El-Rewini, H., \& Abd-El-Barr, M. (2005). Advanced computer architecture and parallel processing. New Jersey: John Wiley \& Sons.

Eliasson, J. (2013). Tools for designing mobile interaction with the physical environment in outdoor activities. (Doctoral Thesis), Stockholm University, Stockholm.

Erikson, K., \& Vogt, H. (2013). On self-service democracy: Configurations of individualizing governance and self-directed citizenship. European Journal of Social Theory, 16(2), 153-173.

Faraon, M., Atashi, S., Kaipainen, M., \& Gustafsson, N. (2011). Using circumventing media to counteract authoritarian regimes. In G. Bradley, D. Whitehouse, \& G. Singh (Eds.), IADIS International Conference on ICT, Society and Human Beings 2011 (pp. 251-254). Rome, Italy.

Faraon, M., Stenberg, G., Budurushi, J., \& Kaipainen, M. (2015). Positive but skeptical: A study of attitudes towards Internet voting in Sweden. In P. Parycek, M. Sachs, \& M. M. Skoric (Eds.), CeDEM Asia 2014: Conference for E-Democracy and Open Government (pp. 191-205). Münster: Edition Donau-Universität Krems.

Faraon, M., Stenberg, G., \& Kaipainen, M. (2014). Political campaigning 2.0: The influence of online news and social networking sites on attitudes and behavior. eJournal of eDemocracy and Open Government, 6(3), 231-247.

Faraon, M., Villavicencio, V., Ramberg, R., \& Kaipainen, M. (2013). From mobilization to consensus: Innovating cross-media services to organize crowds into collaborative communities. In P. Parycek \& N. Edelmann (Eds.), CeDEM13: Conference for E-Democracy and Open Government (pp. 229-242). Krems: Edition Donau-Universität Krems.

Fillmore-Patrick, H. (2013). The Iceland Experiment (2009-2013): A participatory approach to constitutional reform. Retrieved from Democratization Policy Council:

Fox, S. (2000). Communities of practice, Foucault and actor-network theory. Journal of Management Studies, $37(6), 853-868$.

Hibbing, J. R., \& Theiss-Morse, E. (2001). What is it about government that Americans dislike? Cambridge: Cambridge University Press.

Hoff, J. (2004). The democratic potentials of information technology: Attitudes of European MPs towards new technology. Information Polity, 9(1-2), 55-66.

Howard, P., Agarwal, S., \& Hussain, M. (2011). When do states disconnect their digital networks? Regime responses to the political uses of social media. The Communication Review, 14(3), 216-232.

Johansson, D., Lassinantti, J., \& Wiberg, M. (2015). Mobile e-services and open data in e-government processes - concept and design. In M. Younas, I. Awan, \& M. Mecella (Eds.), Mobile Web and Intelligent Information Systems (pp. 149-160). Switzerland: Springer. 
Johansson, D., \& Wiberg, M. (2012). Conceptually advancing "application mobility" towards design: Applying a concept-driven approach to the design of mobile IT for home care service groups. International Journal of Ambient Computing and Intelligence, 4(3), 20-32.

Kaptelinin, V., \& Nardi, B. (2006). Acting with technology: Activity theory and interaction design. Cambridge, MA: MIT Press.

Kemmis, D., \& McKinney, M. (2011). Collaboration as an emerging form of democracy. National Civic Review, 100(2), 2-12.

Klein, H. K., \& Kleinman, D. L. (2002). The social construction of technology: Structural considerations. Science, Technology, \& Human Values, 27(1), 28-52.

Knights, D., Coombs, R., \& Bloomfield, B. P. (1997). Information technology and organizations: Strategies, networks and integration. Oxford: Oxford University Press.

Lackaff, D. (2016). Better Reykjavik - Open municipal policymaking. In E. Gordon \& P. Mihailidis (Eds.), Civic media: Technology, design, practice (pp. 229-234). Cambridge, MA: MIT Press.

Lanzara, G. F. (1999). Between transient constructs and permanent structures: Designing systems in-action. Journal of Strategic Information Systems, 8(1999), 331-349.

Latour, B. (1987). Science in action: How to follow scientists and engineers through society. Cambridge, MA: Harvard University Press.

Latour, B. (1990). Technology is society made durable. The Sociological Review, 38(S1), 103-131.

Latour, B. (1993). The pasteurization of France. Cambridge, MA: Harvard University Press.

Latour, B. (1996a). Aramis or the love of technology. Cambridge, MA: Harvard University Press.

Latour, B. (1996b). On actor-network theory. A few clarifications plus more than a few complications. Soziale Welt, 47(4), 369-381.

Latour, B. (2005). Reassembling the social: An introduction to actor-network-theory. Oxford: Oxford University Press.

Law, J. (1986). Power, action and belief: A new sociology of knowledge? London: Routledge and Kegan Paul.

Law, J. (1999). After ANT: Complexity, naming and topology. The Sociological Review, 47(S1), 1-14.

Layne, K., \& Lee, J. (2001). Developing fully functional e-government: A four stage model. Government Information Quarterly, 18(2), 122-136.

Loader, B. D., \& Mercea, D. (2012). Social media and democracy: Innovations in participatory politics. London: Routledge.

Lotan, G., Graeff, E., Ananny, M., Gaffney, D., Pearce, I., \& Boyd, D. (2011). The revolutions were tweeted: Information flows during the 2011 Tunisian and Egyptian revolutions. International Journal of Communication, 5(Feature), 1375-1405.

Lowe, A. (1997). The role of accounting in the process of health reform: Providing a "black box" in the costing of blood products. Management Accounting Research, 8(4), 439-458.

Mason, P. (2012). Why it's kicking off everywhere: The new global revolutions. London: Verso. 
Meneklis, B., Kaliontzoglou, A., Polemi, D., \& Douligeris, C. (2005). Applying the ISO RM-ODP standard in e-government. In M. Böhlen, J. Gamper, W. Polasek, \& M. A. Wimmer (Eds.), E-government towards electronic democracy (pp. 213-224). New York: Springer.

metagovernment.org. (2015). Active projects. Retrieved from https://web-beta.archive.org/web/ 20150413141400/http://www.metagovernment.org/wiki/Active_projects

Monteiro, E. (2000). Actor-network theory and information infrastructure. In C. U. Ciborra, K. Braa, A. Cordella, B. Dahlbom, A. Failla, O. Hanseth, V. Hepsø, J. Ljungberg, E. Monteiro, \& K. A. Simon (Eds.), From control to drift: The dynamics of corporate information infrastructures (pp. 71-83). New York: Oxford University Press.

Mulder, B. (2014). The strategic value of design for e-democracy. In P. Parycek \& N. Edelmann (Eds.), CeDEM14: Conference for E-Democracy and Open Government (pp. 435-446). Krems: Edition DonauUniversität Krems.

Nazzi, E., Bagalkot, N. L., Nagargoje, A., \& Sokoler, T. (2012). Concept-driven interaction design research in the domain of attractive aging: The example of Walky. In P. Rodgers (Ed.), Articulating design thinking (pp. 227-245). Faringdon: Libris.

Norris, P. (2000). A virtuous circle: Political communications in postindustrial societies. Cambridge: Cambridge University Press.

OECD. (2003). Promise and problems of e-democracy: challenges of online citizen engagement. Paris: OECD.

Olphert, W., \& Damodaran, L. (2005). Dialogue with citizens - The missing link in delivering e-government. Journal of Systemics, Cybernetics and Informatics, 3(6), 32-36.

Papadopoulos, T., \& Wongkaew, M. (2008). The role of inscriptions as interessement devices in the translation of innovative management ideas: implementing Lean Thinking in the UK NHS. Paper presented at the European Institute for Advanced Studies in Management: 1st Workshop on Imagining Business, Said Business School, University of Oxford.

Paulin, A. (2014). Through Liquid Democracy to sustainable non-bureaucratic government. eJournal of eDemocracy and Open Government, 6(2), 216-230.

Peña-López, I. (2011). The disempowering goverati: e-Aristocrats or the delusion of e-democracy. eJournal of eDemocracy and Open Government, 3(1), 1-21.

Quattrone, P., \& Hopper, T. (2006). What is IT? SAP, accounting, and visibility in a multicultural organisation. Information and Organization, 16(2006), 212-250.

Rachel, G., Wainer, L., \& Stephen, W. (2008). The Australian public and politics online: Reinforcing or reinventing representation? Australian Journal of Political Science, 43(1), 111-131.

Rios Insua, D., Kersten, G. E., Rios, J., \& Grima, C. (2008). Towards decision support for participatory democracy. Information Systems and e-Business Management, 6(2), 161-191.

Ritzer, G. (2005). Encyclopedia of social theory (Vol. 1). Thousand Oaks: Sage Publications.

Ritzer, G., \& Stepnisky, J. (2018). Modern sociological theory (8th ed.). Thousand Oaks: Sage Publications. 
Rivera, G., \& Cox, A. M. (2016). An actor-network theory perspective to study the non-adoption of a collaborative technology intended to support online community participation. Academia Revista Latinoamericana de Administración, 29(3), 347-365.

Rogers, Y. (2004). New theoretical approaches for human-computer interaction. Annual Review of Information, Science and Technology, 38(1), 87-143.

Rothstein, D. (2013). Microdemocracy: A new starting point for shared decision-making and democratic action. Paper presented at the 141st APHA Annual Meeting and Exposition 2013, Boston, MA.

Rutherford, T., \& Holmes, J. (2008). The flea on the tail of the dog: Power in global production networks and the restructuring of Canadian automotive clusters. Journal of Economic Geography, 8(4), 519-544.

Sanford, C., \& Rose, J. (2007). Characterizing eParticipation. International Journal of Information Management, 27(6), 406-421.

Sarker, S., Sarker, S., \& Sidorova, A. (2006). Understanding business process change failure: An actornetwork perspective. Journal of Management Information Systems, 23(1), 51-86.

Schneier, B. (1996). Applied cryptography: Protocols, algorithms, and source code in C. New York: Wiley.

Shumow, M., \& Vigon, M. (2016). News diversity and minority audiences. Journalism Practice, 10(1), 52-70.

Smith, G. (2013). Democratic innovations: Designing institutions for citizen participation. Cambridge: Cambridge University Press.

Smith, R. C., Bossen, C., \& Kanstrup, A. M. (2017). Participatory design in an era of participation. CoDesign, 13(2), 65-69.

Stolterman, E., \& Wiberg, M. (2010). Concept-driven interaction design research. Human-Computer Interaction, 25(2), 95-118.

Storni, C. (2015). Notes on ANT for designers: ontological, methodological and epistemological turn in collaborative design. CoDesign, 11(3-4), 166-178.

Storni, C., Binder, T., Linde, P., \& Stuedah, D. (2015). Designing things together: Intersections of co-design and actor-network theory. CoDesign, 11(3-4), 149-151.

Su, C. (2017). From Porto Alegre to New York city: Participatory budgeting and democracy. New Political Science, 39(1), 67-75.

Tomkova, J. (2009). E-consultations: New tools for civic engagement or facades for political correctness? European Journal of ePractice, 7(2009), 45-54.

Trechsel, A. H. (2007). Inclusiveness of old and new forms of citizens' electoral participation. Representation, $43(2), 111-121$.

Vassil, K., Solvak, M., Vinkel, P., Trechsel, A. H., \& Alvarez, R. M. (2016). The diffusion of internet voting. Usage patterns of internet voting in Estonia between 2005 and 2015. Government Information Quarterly, 33(3), 453-459.

Wagle, S., \& Shah, P. (2003). Porto Alegre, Brazil: Participatory approaches in budgeting and public expenditure management (Vol. 71). Washington DC.: Social Development Publications, World Bank. 
Walsham, G. (1997). Actor-network theory and IS research: Current status and future prospects. In A. S. Lee, J. Liebenau, \& J. I. DeGross (Eds.), Information Systems and Qualitative Research (pp. 466-480). Boston, MA: Springer.

Walsham, G., \& Sahay, S. (1999). GIS for district-level administration in India: Problems and opportunities. MIS Quarterly, 23(1), 39-65.

Ward, S., Gibson, R., \& Lusoli, W. (2003). Online participation and mobilisation in Britain: Hype, hope and reality. Parliamentary Affairs, 56(4), 652-668.

Ward, S., \& Lusoli, W. (2005). From weird to wired: MPs, the Internet and representative politics in the UK. Journal of Legislative Studies, 11(1), 57-81.

Warren, M. E. (2012). When, where and why do we need deliberation, voting, and other means of organizing democracy? A problem-based approach to democratic systems. Paper presented at the Annual Meeting of the American Political Science Association, August 30 - September 2, 2012.

Wasserman, S., \& Faust, K. (1994). Social network analysis: Methods and applications. Cambridge, MA: Cambridge University Press.

Weick, K. E. (1989). Theory construction as disciplined imagination. Academy of Management Review, 14(4), 516-531.

West, D. (2004). E-government and the transformation of service delivery and citizen attitudes. Public Administration Review, 64(1), 15-27.

Wolf, M. (2010). Sociology of translation. In Y. Gambier \& L. v. Doorslaer (Eds.), Handbook of translation studies (Vol. 1, pp. 337-343). Amsterdam: John Benjamins Publishing Company.

Yuanbo, Q. (2017). The openness of Open Application Programming Interfaces. Information, Communication $\mathcal{E}$ Society, 20(11), 1720-1736.

Zanello, G., \& Maassen, P. (2011). Strengthening citizen agency and accountability through ICT. Public Management Review, 13(3), 363-382.

Zissis, D., Lekkas, D., \& Papadopoelia, A.-E. D. (2009). Competent electronic participation channels in electronic democracy. Electronic Journal of e-Government, 7(2), 195-208.

\section{About the Author}

Montathar Faraon, PhD

Montathar Faraon is an interaction design researcher with an interest in co-creation, participatory processes, ICTs for democracy, and concept-driven design. He is an Assistant Professor in the Department of Design of Kristianstad University, Sweden.

\section{Dedication}

To the memory of my late father, Sahar Faraon. I will always and forever hold you in my heart and mind. 